p. I 83 Bull., Bigot, in his characteristic way, proposes a new generic name, Pseudarchilestes, for Dasypogon albitarsis Macquart. The author could have hardly comprised more errors in one short note than he has done. First, Schiner first described the genus Archilestes (Archilestris) in the Verh. zool.bot. gesellsch. 1866, v. 16, p. 672, and not in Reise der österreichischen fregatte Novara, which appeared two years later. Second, he says nothing about D. magnificus Walker, being the same as $D$. albitarsis, but, on the contrary, places $D$. albitarsis as a synonym of D. capnopterus Wied.(op. cit., v. I6, p. 703 ; v. 17 , p. 377), the type of the genus. Had Bigot been at all familiar with what Schiner has written, he would have observed that Schiner says expressly (Verh. zool.-bot. gesellch. v. i7, p. 378 ) that the third antennal joint in A. capnopterus is "auf der Oberseite behaart," the very identical character that Bigot assumes as distinctive of his Pseudarchilestes! Furthermore, Schiner says nothing in his original generic description about the third joint not being hairy above. That he does say so in a later description was undoubtedly an oversight, that should not have been accepted so heedlessly. In a word, Bigot erects a new genus upon the type species of another genus, based upon a character that was expressly stated to be present in that type. Archilestris magnificus Walk. has, likewise, the "third joint of the antennae distinctly beset with hairs on the upper side." (Osten Sacken, Biol. Cent.Amer., p. 169.)

I wish to substitute Myiothera for Lynchia, p. 255, as I find the latter was used by Weyenbergh in $\mathrm{r} 88 \mathrm{r}$.

\title{
NOTES ON THE EARLY STAGES OF SOME HETEROCERA.
}

BY CAROLINE G. SOULE AND IDA M. ELIOT.

PANOPODA RUfimargo, VAR. ROSEIcosta, Guen.

This larva was .28 $\mathrm{mm}$. long, bright green, and found feeding on oak in Nonquitt, Mass., on ro September, I889.

The head was large, bright green, minutely speckled with black, and having a horizontal yellow line across the "forehead."

The body was bright, rich green, minutely speckled with black, and hav- ing subdorsal lines of bright yellow extending from the head to the end of the anal props.

On the first segment were four small yellow dots just behind the head, and two larger ones behind the four.

On the first and second segments were a faint yellow horizontal line, and three rough yellow tubercles.

There was a dorsal line of yellow dashes and the space on each side was 
dotted with yellow, the dots becoming more numerous after the fifth segment.

There were nine obliques of clear yellow, their "trend" being the reverse of those of Sphinx larvae.

The feet and props were pale green with reddish tips, except the anal props, which were long, thin, and like the body in color.

All the props ended in curved and speading tips. The last moult was like the one before it, and occurred one week before the larvae spun leaves together for pupation. The pupa formed in five days from the spinning and was of a light brown color with no noticeable peculiarity. The moth emerged in June, I889, and was kindly identified by Mr. John B. Smith.

Callosamia angulifeka Walk.

These eggs were sent us by Miss Emily L. Morton, with no date of laying, but the egg-period is probably about that of $C$. promethea.

The eggs closely resembled those of C. promethea, but were whiter.

Many of the eggs turned lead color by July 20 , but a few became green, and a few yellow. All hatched on 20 July.

The young larvae were $4 \mathrm{~mm}$. long, and bright yellow with a dark head. The head had two light bands across it. There was a black transverse band on the top of the second segment. The anal segment had two dark transverse lines, and a dark line showed faintly between the segments.

The feet were grayish yellow with dark tips. Props yellow. Each seg- ment had six warts and spines, except the first and last which had four.

27 July. First moult. Head yellow with a dark line and dark patch across it.

Each segment had two transverse black lines on dorsum. Body-color greenish yellow. On the first segment were, four black warts with black spines. On the eleventh segment were three warts, the middle and largest one being on the dorsal line, and two warts just behind these. On each of the other segments were six yellow warts with yellow, black-tipped spines. Anal shield with a transverse line and patch of black. Feet and props pale yellow.

3I July. Second moult. Head pale green with dark mouth-parts.

Body whitish green, with two indistinct black lines on each segment, and a transverse row of yellow warts, each having a spreading crown of yellow spines. Just behind the head the row of warts was followed by a heavy black line.

Feet and props whitish green. Anal shield with a black line and patch.

6 Aug. Third moult. Head green, with black dots over the top and a black line across the face just above the mouth-parts.

Body very white-green, smooth, tapering from third segment to the anus.

From the third segment to the anal shield, there was a thick wavy ridge just below the spiracles. This ridge is one of the differences between these larvae and those of promethea. It 
has been very noticeable in all the anguiifera-larvae we have seen.

First segment. Two small yellow tubercles over the head, then on each side, two black, raised dots, and one just above the foot.

Second and third segments. Two large tubercles on the dorsum, black at base, ringed with yellow, orange at tips, smooth ; two black points on each side, and one over the foot.

Two other segments, to the eleventh had, each, six black, raised points.

Eleventh segment. One large dorsal tubercle, of clear yellow ringed with black, and two black points on each side.

Twelfth segment. Four black points and two black tubercles on the anal shield. Anal shield and props edged with yellow, the props having a "horseshoe" of black on the outer side. Stigmatal ridge conspicuous. Feet and props whitish green.

I 2 August. Fourth moult. As before, but larger, and having tubercles of a bright coral red, instead of orange. These tubercles were ringed with yellow, and were black at base. The black "horseshoe" on anal props became a triangle of black, and each abdominal prop had a black dot on the outer side.

The yellow-white, stigmatal ridge, extending from third segment to anal shield, was very noticeable.

Spiracles inconspicuous.

23 August. Began to spin. Just before spinning the larvae measured nearly $75 \mathrm{~mm}$. in length, and $44 \mathrm{~mm}$. around the largest part of the body.
The dots and tubercles were small in proportion to the size of the larvae, and less conspicuous than those of promethea larvae. The tubercles were not erect like those of promethea larvae, and were ringed with yellow,-a marking which we have never found on promethea. The body was cream-colored above and somewhat greener on the venter, the yellow, stigmatal ridge, making a definite scalloped edge, ending in the anal flap.

The head was small in proportion.

The tubercles, the stigmatal ridge, and the smoother, creamier color form the most marked differences between promethea and angulifera larvae, which still closely resemble each other.

We have never seen an angulifera larva which would eat anything but the leaves of tulip-tree (Liriodendron tulipifera), while promothea larvae will eat almost any leaf !

The cocoons of angulifera were rounder, and in no case did the larva spin threads around the leaf-stem, or fasten the stem to the twig, while the promethea larva did this in every box where twigs were provided.

We feel that the two kinds are distinct and separate, although we have some promethea $\&$ mot'ss which are very near angulifera in their markings. The $\delta$ angulifera varies more from the $\delta$ promethea than the $q$ from $q$ promethea, although, in typical speci mens, the difference is very marked.

\section{Pheosia Rimosa Pack.}

Eggs, found on a poplar leaf, Nonquitt, Mass., 28 August, 1888. They 
were white, opaque, hemispherical, and suggested eggs of butterflies, though they were smooth.

2 September. They hatched. Young larva $3 \mathrm{~mm}$. long. Head, feet and props shining black.

Body whitish-green, with a subdorsal row of black spots, two to each segment; lateral row one to each segment.

Eleventh segment, a black dorsal tubercle.

First segment had a raised black patch, and looked swollen.

Second and third segments, two large black dorsal spots. Anal end black. Sparse hairs all over the body.

7 September. First moult. $19 \mathrm{~mm}$. long. Head black above, and brown on face. Feet and props black.

Body green with slight yellow striations, and a black horn on the eleventh segment.

Io September. Second moult. 28 $\mathrm{mm}$. long.

Head paler than the body, which was of a greenish-purple color, with the venter green, and a dorsal line somewhat darker than the body. Spiracles, conspicuous for the first time, black dots encircled with white.

14 September. Third moult. $3^{8}$ $\mathrm{mm}$. long. Head and body slate-gray, very smooth and shining. Anal shield rough, and the whole segment with a reddish tinge.

Caudal horn black, and from its base two black lines extended to the last spiracles.

Feet and props like body. Spiracles as before.

22 September the first one pupated.
Pupa, $25 \mathrm{~mm}$., or slightly shorter, brown, smooth, slender.

First imago emerged 6 June, I 889.

IChthyura inclusa, Hubn.

At Nonquitt, Mass., I 2 July, I888, we found on a poplar leaf, and almost covering it, a close mat of tiny eggs of the color and bloom of Delaware grapes. 3o July these hatched, giving larvae of a grayish color, with black heads, with stiff hairs, which, when the larvae were in motion, made them look as if they had props on each segment. There were black dots on each segment, and these were confluent on the first segment, making a black collar. Anal props were black.

The larvae were very restless, and ate only the pulp of the leaves. They grew greenish in a day or two.

8 August. They moulted. Head black, body green, with a few scattered hairs; collar black as before.

Fourth segment had a black dot on the back, as had the anal segment.

There were rows of black dots, lateral and sublateral, with black "speckles" between.

I5 August. Second moult. Head black. Body yellow with sparse white hairs. On fourth and anal segments a black wart.

Dorsal and subdorsal longitudinal black stripes meeting at the black anal wart. A wider sublateral black stripe made of confluent dots; and a subventral black stripe. On these two stripes were black warts, one on each segment, and from these warts arose the white 
hairs. Feet black. Props yellow, with black dots.

I9 August. Third moult. Head and body color as before. Dorsal stripes and warts as before. Sublateral and subventral stripes dark gray with black lines through them, and with warts as before.

On the first and second segments two additional warts, making six on those serments and four on the others.

Feet black. Props yellow with black dots. Spiracles black. Soft, fine hairs all over.

2 September. Fourth moult. 44 mm. long, slightly hairy.

Head black, with white hairs scattered over it.

Rody almost black with four dorsal lines of bright yellow ; one bright, and several indistinct, lateral lines, and marks of yellowish.

On fourth segment a bifid black tubercle, giving rise to white hairs. On anal segment a smaller black tubercle. Subventral surface with considerable yellow.

Feet and anal shield black. Props yellowish-brown.

28 August. The larvae began to spin, either loose cocoons in corners of the tin, or inside leaves drawn together.

Pupa, ${ }_{5} \mathrm{~mm}$. long, of a bright chestnut brown color. First imago emerged

Spilosoma congrua, Walk.

At Nonquitt, Mass., 7 June, r889, we found a nest of small, opaque, white, globular eggs on a leaf of Trifolium agrarium. These eggs were exactly like some received the same day from Miss Morton, and laid by a $\$$ Spilosoma congrua. We found several moths of $S$. congrua, flying in Nonquitt this year.

We watched the larvae through all their moults, comparing the two sets daily, and they proved the same throughout.

The eggs turned lead-colored the day before they hatched. They hatched 9 June. The young larvae were $4 \mathrm{~mm}$. long, with black heads.

Body yellowish, with dark warts, from which sprung gray or black hairs. Anal shield dark. Feet and props like body.

They ate clover, but much preferred plantain even to the Trifolium agrarium on which the eggs were laid.

When touched they curled up and dropped from the leaf, like the other "woolly bears."

I4 June. First moult. $6 \mathrm{~mm}$. long. Head black. Body-color yellow, with black transverse dorsal lines between the segments; third and tenth segments darker in color. Feet and props like body. Warts dark, with sparse blackish or dark gray hairs.

I7 June. The black transverse lines disappeared and the color on and around the warts was deep brownishyellow.

I8 June. Second moult. Head black. Body color deeper and browner yellow; warts darker, with hairs longer and more numerous.

22 June. Third moult. $15 \mathrm{~mm}$. 
long. Head and feet black. Bodycolor darker and browner than before, with a dorsal white line, and lateral orange line, broken between the segments.

Warts shiny black, with short very black hairs, growing in tufts.

27 June. Fourth moult. $21 \mathrm{~mm}$. long. As before, only bigger and blacker, and with the hairs longer. Orange laterals deeper and brighter.

They move very rapidly with a quick, jerky motion, stopping suddenly when at the fastest speed.

4 July. Fifth moult. As before, only larger, and with denser hairs.

Io July. They were from $25 \mathrm{~mm}$. to $29 \mathrm{~mm}$. in length. Most of them were very active and voracious. If left without food for even a short time they would eat such of their number as were preparing to spin, and were therefore less vigorous than the rest!

I I July. Began spinning. Unless the cocoons of the earlier spinners were removed the pupae would be found half devoured by the larvae not yet ready to spin, even when there was plenty of food plant in the boxes.

The cocoons were oval, thin, with hairs spun into them. Pupa of bright chestnut color, short, stout.

Cressonia juglandis, A. \& S.

Eggs, ovoid, pale green, laid about 7 July. They hatched 17 July; having grown yellow the day before.

Young larva, $9 \mathrm{~mm}$. long, pale yellow, with short, yellow caudal horn; feet and props concolorous with body.
Anal props extended, in trailing points, beyond the anal shield.

They ate walnut.

21 July. First moult. I5 mm. long, slightly rough. Head green, with a long, conspicuous point on the apex.

Body, feet, props, and caudal horn green.

The body had a longitudinal white line on each side of the dorsal line, extending from head to horn.

The larvae drank greedily. In two days the caudal horn grew brownish, and faint yellow obliques appeared.

27 July. Second moult. Head green, with two long brownish filamentous points at apex. From these points a brownish line extended down the back of the head. The head was granulated with yellowish-white points, and had yellow face-lines.

Body green, granulated with yellowwhite, and having yellow obliques and subdorsal lines.

Feet and props green, the anal props having the trailing points as before.

Caudal horn brownish and granulated.

I August. Third moult. Head green, very pointed, with white facelines, and very bifid apex.

Body green, and, as well as the head and horn, thickly granulated with yellow white points. Horn long and usually beld level with the body. Anal shield had two largish white tubercles.

8 August. Fourth moult. Head less pointed, though still shaped like an apple-seed.

Body as before. Anal shield bisected 
by a vertical black line on each side of which was a white wart.

The long points on the head were replaced by reddish granules.

\section{Spiracles red}

The effect of the body was like the rough underside of the walnut leaves.

I 5 August. The white granules had become encircled by purplish brown lines, the lines being broader around the granules forming the obliques. The body was largest at the anal segment, and tapered rapidly to the head.

29 August. Stopped eating, being about $75 \mathrm{~mm}$. long.

7 September. Pupated. As our specimens failed to cast the larval skin, the pupae were not sufficiently perfect to describe. We therefore quote Prof. Fernald's description, in his "Sphingidae of New England."

"The pupa is blackish brown, and roughened over the entire surface. There are four little prominences on the head case, and the terminal segments are flattened on the ventral surface, and have lateral, toothed appendages."

Our larvae did not correspond exactly with Prof. Fernald's description.

\section{Paonias a stylus, Drury.}

On 7 July, $\mathrm{I} 889$, a $\$$ astylus emerged from a pupa formed by a larva found in the previous September. The moth was fastened outdoors the next night, but no $\delta$ was seen.

On 9 July she laid about sixty eggs. These were ovoid, and apple-green in color.

19 July. They turned yellow with an opaque green line, and the red caudal horn could be clearly seen.

20 July. The young larvae came out, eating only enough shell to allow them to pass, and crawling for hours with the iridescent shell still over the caudal horn.

Newly hatched larva. Head, green, round, with dark mouth-parts and a dark dot close to the palpi, on each side.

Body, pale green, granulated, with slight indications of yellow subdorsal lines from the head to the caudal horn. Caudal horn short, stout, rough, red at hase, yellow in the middle, very dark red at tip, which was markedly bifid.

Feet and props green.

Ate Vaccinium corymbosum, and, afterward, Gaylussacia frondosa.

29 July. First moult. As before, except that the head was more pointed, the horizontal yellow lines were clearer, and the feet were red.

4 August. Second moult. As before, only larger, being $19 \mathrm{~mm}$. long.

I 2 August. Third moult. Head pointed, bright green, granulated.

Body bright green, granulated with yellow white. Red dots and patches began to appear, set irregularly between the dorsal and subdorsal lines.

Faint yellow obliques appeared. Caudal horn short, stout, inclined forward, yellow around the base, then red, then yellow in the middle, and deep red at tip. It was granulated with rough tubercles most noticeable at the tip, which was formed by two pointed tubercles with a slightly smaller one between them. 
These tubercles gave a very different effect from the bifid tips of the earlier stages, and, without a lens, the horn looked blunt at the tip.

Feet and props red-tipped.

2 I August. Fourth moult. Head less pointed, color as before.

Body green, less roughly granulated with yellow.

Yellow obliques clearer. Yellow horizontal lines confined to the first three segments; and faint sublateral lines of yellow dots appeared on these segments.

The red dots and patches were more numerous, and of a clear, bright red. Four red dots appeared on the anal shield.

Feet and props red-tipped.

Spiracles, heretofore unnoticeable, were bright red. Caudal horn short, stout, very erect, green at base, then red, ringed with yellow in the middle, and tipped with deeper red, though not as dark as in the earlier stages.

The "bifid tip" was reduced to an ordinary tip ending in two small granules, not seen without a lens.

29 August. The red patches were larger and more numerous. In one specimen they filled the dorsal spaces between the obliques on the segments fourth to tenth inclusive. This specimen had a substigmatal row of red dots, wanting in the others. The caudal horn was less bright in color, and very short in proportion to the size of the larvae, which was now about $63 \mathrm{~mm}$. long.

Mr. Peck, quoted by Mr. John B. Smith in his "Monograph of the Sphin- gidae," states that the "bifid tip" of the caudal horn or "these spines" forming the "bifid tip" "are constant from its hatching," but in no specimen which we have seen has this been the case. Nor have the colors of the horn been such as he describes them. Instead of a brownish or red-brown, the color has been, in every instance, a clear, bright red, matching the leaves of the high huckleberry and blueberry when "turning" in the autumn. In fact, the whole larva, when full grown, had the exact colors of these leaves, and the horn looked like the buds "set" for the following spring!

The larvae were very delicate, many dying in moulting, and those found were very subject to parasites.

5 September. Stopped eating and prepared for pupation.

\section{September. Pupated.}

Pupa of a rich chestnut brown color, with a sharp point on anal end.

$3^{1} \mathrm{~mm}$. long, neither slender nor stout.

\section{Paonias myops, A. \& S.}

Eggs roundish, green, laid 9 June and hatched 24 June.

Young larvae, pale yellow-green with pointed heads. Ate wild cherry.

3o June. First moult. Head green, pointed at apex. Body green, feet, props and horn concolorous with body.

3 July. Faint yellow oblique, and a horizontal yellow line on the first three segments appeared, also indistinct red spots.

5 July. Second moult. $19 \mathrm{~mm}$. 
long. Head green and very pointed, ending in a yellow dot at apex.

Body green, with, on each side, a yellow horizontal on first three segments, seven yellow obliques, each crossing two segments, and meeting its mate on the dorsal line. Red spots on dorsum and sides, irregularly placed, and varying in size, number, and position in the different larvae. Body thickly granulated with yellow dots.

Caudal horn short, red above and below, yellow on each side, from the last obliques.

Feet and props green, anal shield pointed.

I4 July. Fourth moult. 3I $\mathrm{mm}$. long. Head green, pointed, and with faint yellowish lines on each side.

Body green, with horizontal lines as before. Yellow obliques more distinct, the last ones being yellower and wider than the others, and reaching part way up the caudal horn.

Anal shield pointed, and edged with yellow. Caudal horn short, red above, green beneath, yellow at the sides.

Feet reddish, props green, spiracles yellow. In some specimens, the spiracles were set in small red patches.

The red spots varied very much in the different specimens, those on the fifth segments being most found.

In three specimens the red spots were surrounded by yellow.

In all the spots were of a clear, bright red, and not at all of the "brownish red" referred to by some writers.

The bodies were thickly granulated with yellow.
20 July. Stopped eating.

27 July. Pupated.

Pupa of a chestnut brown color, darker than that of Dolba hylaeus; smooth, neither slender nor stout, and about $3 \mathrm{I} \mathrm{mm}$. long.

\section{Dolba hylaeus, Drury.}

A 9 , caught in Nonquitt, Mass., by a little girl, laid eggs between 6 and 15 August, the child did not notice the exact date.

The eggs were small, oval, pale green, becoming yellowish two days before hatching. They hatched on I7 August.

Young larva, $6 \mathrm{~mm}$. long, pale green, with a caudal horn as long as the body. The horn was green at first, but grew black in two hours.

The larvae ate inkberry (Prinos glabra) but would not touch sweet fern.

They grew pinkish after eating, especially near the head and just before the caudal horn. Like most young sphingid larvae they spun silken threads as they moved about.

24 August. First moult. They became greener, and showed a faint white line on each side of the dorsum, extending from the head to the caudal horn. Feet and props concolorous. The horn was black, the segments around the base being whitish green. They ate their skins, except horn and mask, after each moult.

3I August. Second moult. Pale green, with a dark dorsal line, edged on each side with white, extending from head to horn. 
Seven faint, yellow-white obliques could be seen on each side, the last being yellower and wider than the others, and extending half-way up the horn.

6 September. Third moult. 25 $\mathrm{mm}$. in length. Head green, rounded. Body green, whites on dorsum, with a deep green dorsal line. The white lines on each side of the dorsal line were hardly to be distinguished from the whitish dorsal surface.

There was a yellow, horizontal, lateral line, broken by the obliques, which were yellow edged in front with dark green.

The caudal obliques were yellower and broader than the others, and extended a little way up the horn. The horn was long, sharp, and rough, green at base, almost black elsewhere.

Feet and props green.

8 September. The body showed yellow granulations more dense on first three segments.

The yellow horizontal lines were confined to these three segments, and the last obliques grew whiter than the others, and were edged in front with blue-black.

The head was thickly granulated with blue-black. Feet red-brown at tips.

One specimen had the caudal horn of olive-green, very light at the tip.

I I September. Fourth moult. Head round, green, granulated.

Body green, granulated with yellow on the first three segments, venter, and the anal shield.

Dorsum very white-green, bisected by a deep green line from head to horn.

Yellow horizontals gone.

Obliques whiter, edged in front with dark green and a trace of blue-black. Last obliques much whiter, with a definite edge of blue-black.

Spiracles, noticeable for the first time, -blue-black encircled with white.

Caudal horn green at base and sides, blackish green above, and lighter beneath ; slightly rough, sharply pointed, slender and long.

Feet green at base, ringed with yellow, tipped with blue-black. Props green. Anal shield edged with yellow green.

I 7 September. Fifth moult. Head blue-green dotted with small, dark granules. Mouth-parts dark.

Body yellow green, with the dorsum very white-green. First three segments granulated with white and venter slightly so. Obliques bright pink shading into yellow on the dorsum, and edged in front with deep green. The last obliques had white in place of the yellow, and continued, as white granules, one-third the length of the caudal horn.

Horn blue-green above and beneath. Anal shield slightly edged with yellow.

Dorsal line very blue-green edged on each side with white.

Feet green, and ringed with yellow, and with blue-black tips. Length $3^{8}$ $\mathrm{mm}$.

In two days the dark green edges of the obliques and of the horn had become very purple-black, the purple showing most beneath the horn.

26 September. $56 \mathrm{~mm}$. long. As 
before, except that the yellow granules were very indistinct; and the obliques next the head could hardly be traced.

The other obliques were bright pink, edged with deep blue-purple. Caudal horn was green at base, and blue-purple elsewhere, the "blue-purple" being of the exact tint of very ripe inkberries. Horn short in proportion to size of the larvae.

The spiracles were dark in ovals of white, these ovals being encircled by faint blue-purple lines. They were small, and merged in the pink obliques on six segments, but conspicuous on the others.

2 October. Stopped eating, being then $63 \mathrm{~mm}$. long.

ro October. Pupated.

The pupa was $3 \mathrm{I} \mathrm{mm}$. long, neither stout nor slender, with a tongue-case 9 $\mathrm{mm}$. long, and lying close against the body. Its color was green at first, and showed the dark obliques on the abdominal segments, but in two days it became bright brown. There was a point on the anal end, but no hook.

\section{THE MALE ELEMENT THE ORIGINATING FACTOR IN THE DEVELOPMENT OF SPECIES.}

BY JEROME MCNEILI, MOLINE, ILI.

Professor W. K. Brooks, in his study of the philosophy of heredity ${ }^{1}$ has advanced a new theory which offers a reasonable explanation of the means by which ancestral characters may be preserved in any species and at the same time new variations transmitted to posterity. Without attempting to state the theory in full (this is the more unnecessary because it is probably known to a large majority of the readers of Psyche), it will be sufficient for the present purpose to say that the author considers that "the male element is the originat-

1 The law of heredity, by W. K. Brooks, Associate on biology at Johns Hopkins university. Published by John Murphy and co., Baltimore. ing and the female the perpetuating factor in the evolution of species." $\mathrm{Mr}$. Brooks offers no more convincing arguments in support of his views than the evidence from sexual characters, and while the illustrations drawn from entomology are probably the best that could be selected, it has seemed to the writer that it might not be uninteresting to note the application of the theory to the genera and species of as little known and little studied an order as that of orthoptera. In presenting this evidence I shall collocate it with the five propositions formulated by $\mathrm{Mr}$. Brooks.

I. "In most animals of separate sexes, the males of allièd species differ 

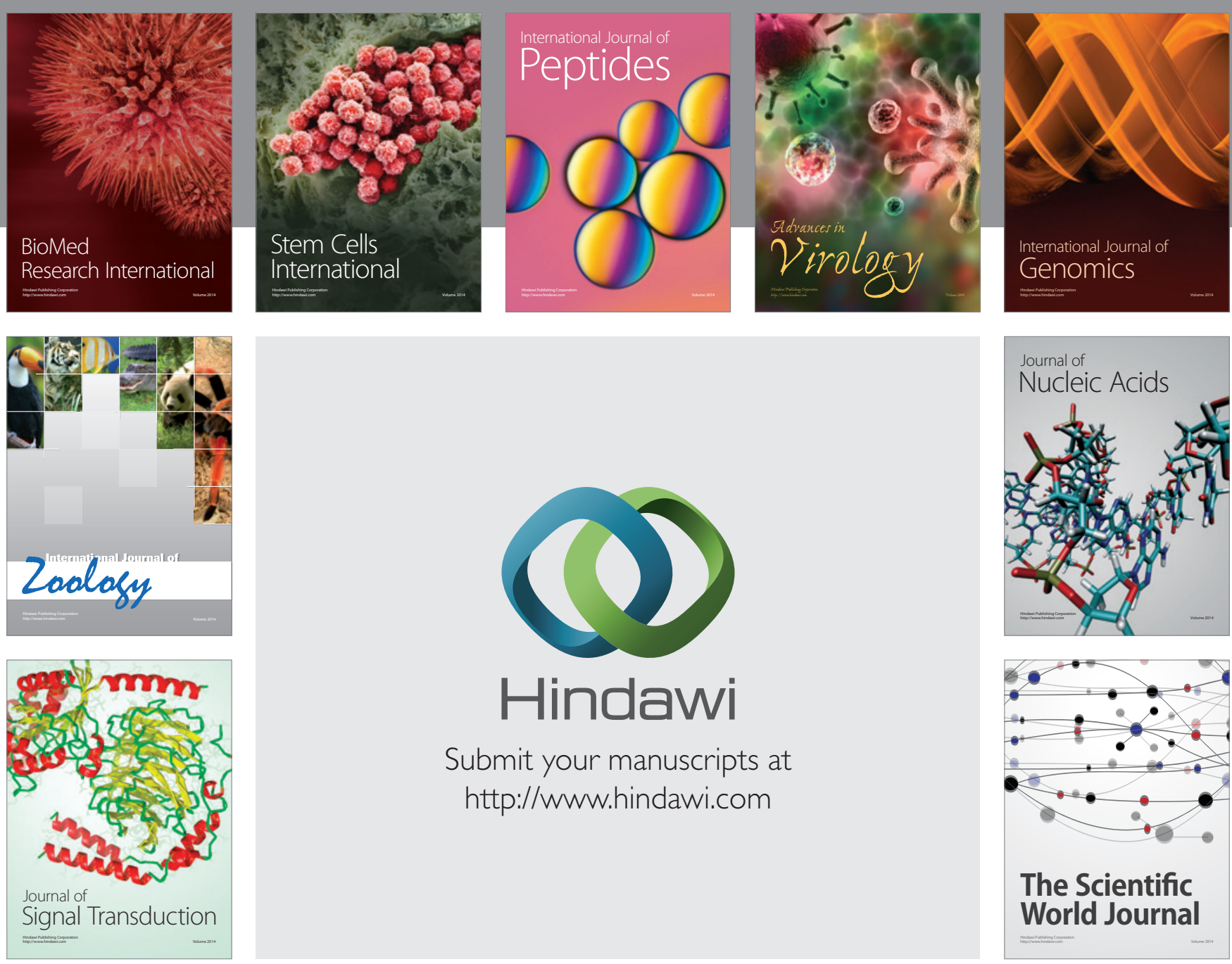

Submit your manuscripts at

http://www.hindawi.com
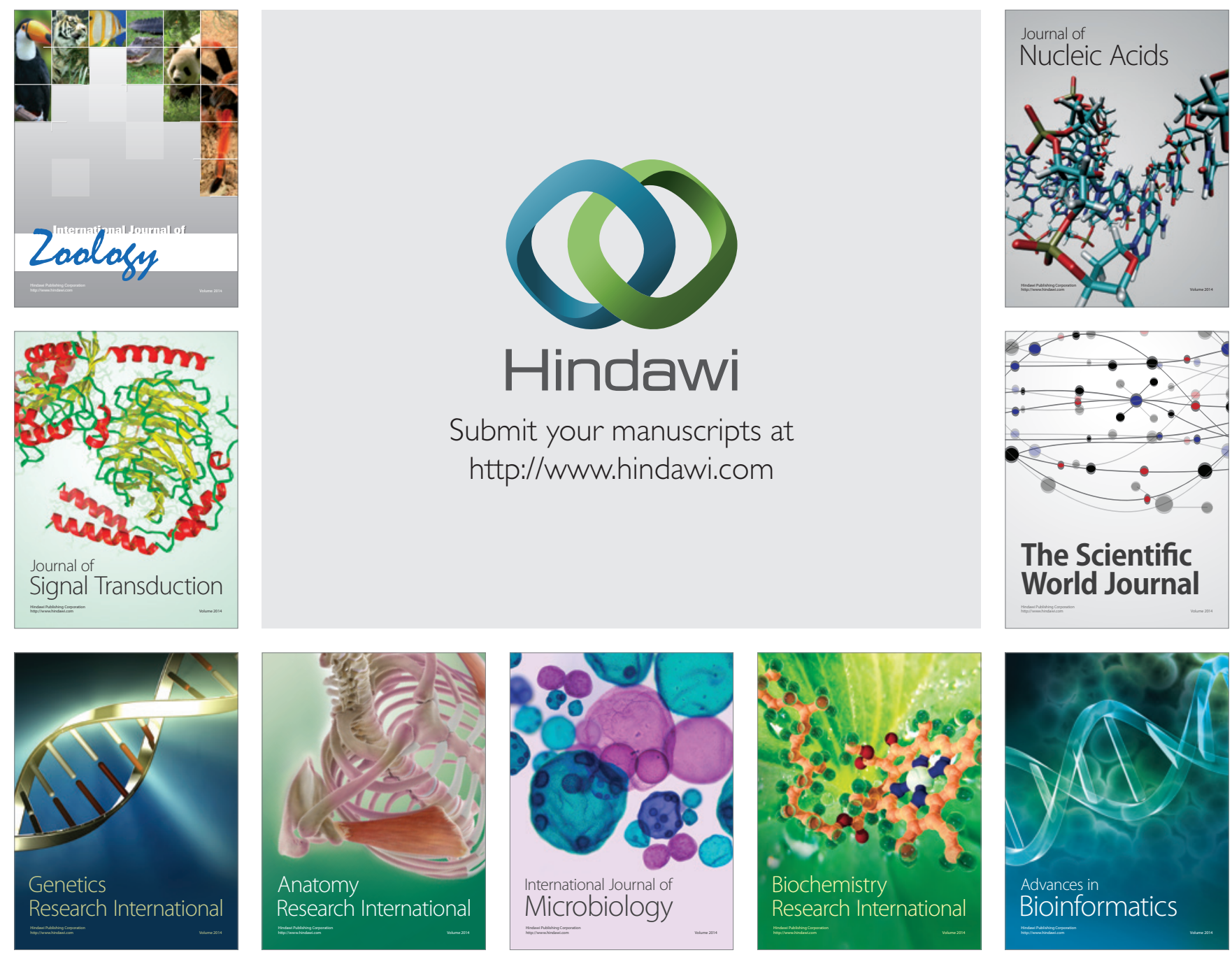

The Scientific World Journal
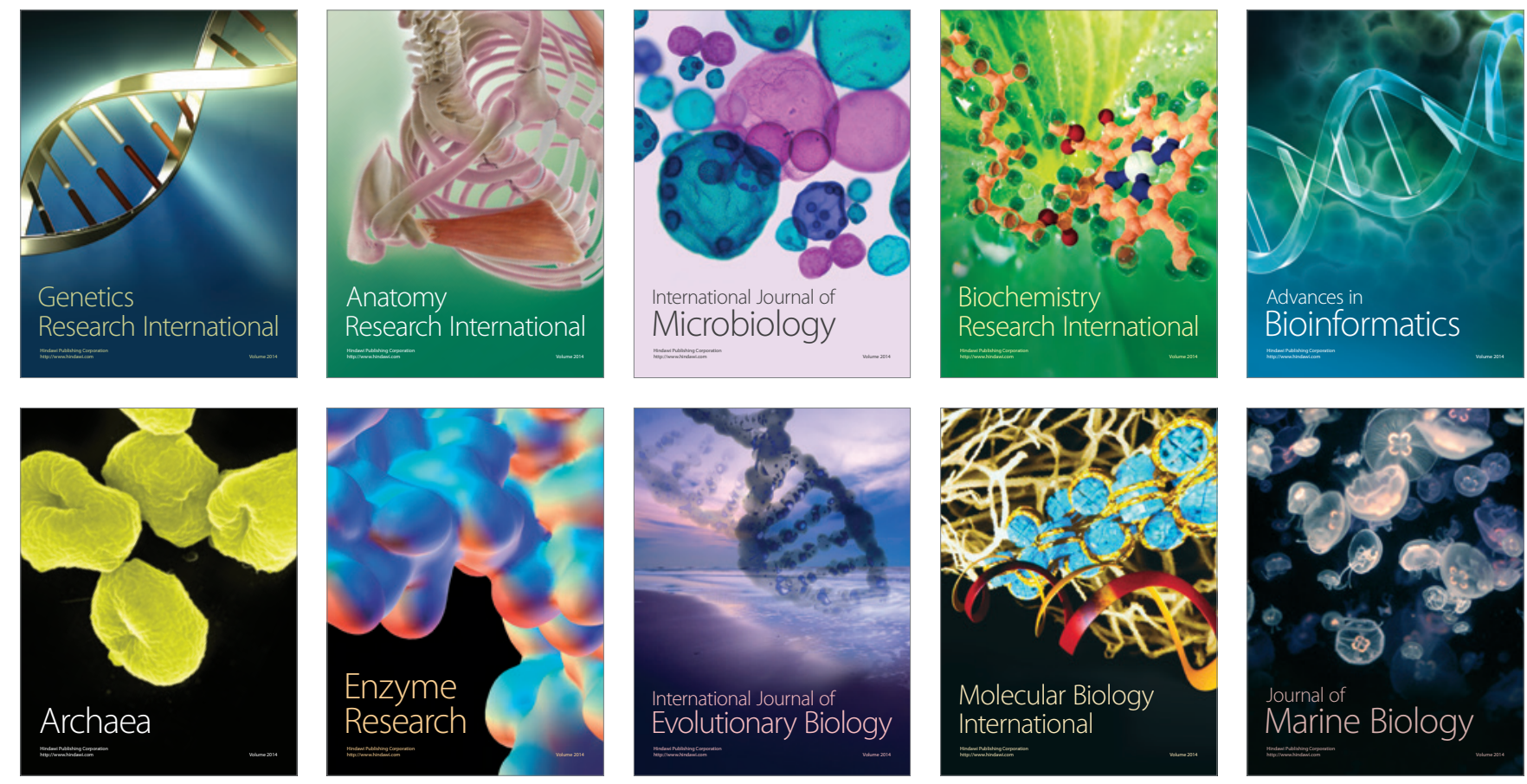